\title{
The Influence of Extracurricular Activities on Character Building of Students of SMPN 22 Makassar
}

\author{
Jamaluddin', Syahrani Syam², Sirajuddin $\operatorname{Saleh}^{3}$, Nasrullah $^{4}$ \\ 1,2,3,4 Office Administration Education,Universitas Negeri Makassar, Indonesia \\ E-mail: jamaluddin8002@unm.ac.id
}

\begin{abstract}
The influence of extracurricular activities on character building of students at SMPN 22 Makassar. This study aims to determine the effect of extracurricular activities on the formation of student characters at SMPN 22 Makassar. This research is a quantitative study with a population of 505 students. The sample used in this study was 15 percent or 71 students. Data collection techniques used were questionnaire techniques (questionnaire), interviews, and documentation. The data analysis technique used is descriptive statistical analysis and inferential statistical analysis. The results showed that the extracurricular activities of the students at SMPN 22 Makassar were in the quite good category with a percentage level of 56.88 percent which was seen from the indicators of krida and training/talent/achievement indicators and for the character of the students in the good category with a percentage level of 78.38 percent which was reviewed from indicators of a religious character, discipline, hard work, creative, independent, democratic and responsible. Based on the product-moment correlation analysis, it was stated that there was a relationship between extracurricular activities and the characterbuilding of students in the medium category. The results of the simple regression analysis show that there is a positive and significant effect of extracurricular activities on the character building of students of SMP Negeri 22 Makassar.
\end{abstract}

Keywords: Extracurricular, character, students.

\section{INTRODUCTION}

The problems of the Indonesian people in various fields so far cannot be separated from the character and values of society (Ma'rifataini, 2017; Rozi \& Sunarsi, 2020; Sufriadi et al., 2019) If there are currently many criticisms related to the character of the nation, then schools as one of the educational institutions are also responsible for overcoming these problems. As stated in Law no. 20 of 2003 Article 3 concerning the National Education System states that national education functions to develop capabilities and shape the character and civilization of a nation with dignity in the context of educating the nation's life.

In 2010, character education began to be held to be carried out in schools in stages, starting from elementary schools, junior high schools, high schools, and vocational high schools. In fact, since the 2013 school year, schools have started to implement the 2013 curriculum, where the curriculum is character-based. Where the character itself is traitor moral that distinguishes humans from animals. People who have good character and are strong individually and socially are those who have good character, morals, and character. Our country wants all people to be 


\section{Jurnal Office: Jurnal Pemikiran Ilmiah dan Pendidikan Administrasi Perkantoran \\ Vol. 7, Number. 1, January-June 2021, Hal 1-10}

educated to become Pancasila humans in which character values and strong religious beliefs are formed.

Therefore, the government established regulations on character education and strengthened by Presidential regulation Number 87 of 2017 article 3 (Hanung Cahyono, 2017) which states that "Strengthening Character Education (PKK) is implemented by implementing Pancasila values in character education, especially those which include religious values, honesty, tolerance, nationality, love for the country, respect for achievement, communicative, communicative, peace-loving, fond of reading., care for the environment, care socially and be responsible. To address this, it can be realized through character education that should have been instilled from an early age. Character education is a process of shaping, directing, and developing a person's personality and abilities. Personality or character development is only possible through the influence of the environment, especially education.

In the world of education, character education can be integrated through the learning process, extracurricular activities, and culture in schools. To be able to make this happen, the school as an educational institution is a place for the teaching and learning process to take place (Arhas, 2018; Darwis et al., 2019; Saleh et al., 2019). Also, schools are not only a place for the teaching and learning process to take place but schools are also a forum for making efforts to develop the potential possessed by students. So extracurricular is a form of self-development efforts of students outside of the learning program (Annu \& Sunita, 2013; Darling et al., 2005; Eccles et al., 2003; Fredricks, 2012; Shulruf et al., 2008). Extracurricular activities are held as a forum for students who are tailored based on their interests, talents, and needs. Extracurricular benefits for students as it can improve student abilities in both cognitive, affective, and psychomotor aspects, as well as develop talents and interests of students and foster positive personalities.

SMPN 22 Makassar is one of the schools that accommodates students with extracurricular activities consisting of the Intra School Student Organization (OSIS), Praja Muda Karana (PRAMUKA), the Center for Information and Youth Counseling (PIK-R), and Rohit's. SMPN 22 Makassar is active in carrying out extracurricular activities. Student Council. Pramuka, PIK$\mathrm{R}$, and Rohit's are extracurricular activities that have many benefits such as developing abilities and a sense of social responsibility as well as how to form student character. Also, the school is very active in helping students to develop their interests, talents, and personality/character such as providing routine training and helping students to participate in competitive activities. Students who take extracurricular activities are more confident and polite. Not only that, students who are active in these activities are more disciplined and responsible for each task they carry out. This shows how much influence and importance these extracurricular activities have.

\section{METHOD}

This type of research used by researchers is a correlational type of research with a quantitative approach. To find out the size or height of the relationship is expressed in the form 
of a correlation coefficient. According to Sugiyono (2018), The quantitative research approach can be interpreted as a research approach based on the philosophy of positivism, used to examine certain populations or samples, sampling techniques are used randomly, data collection uses research instruments, data analysis is quantitative/statistical to test predetermined hypotheses.

The total population was 505 students and the sample was determined by proportionate stratified random sampling based on Riduwan Dalam's opinion (Niswaty \& Arhas, 2019) as much as 15 percent or 71 students. While the data collection techniques used are questionnaire techniques (questionnaire), interviews, and documentation. The data analysis technique used is a descriptive statistical analysis (Sugiyono, 2017) is a statistic that is used to analyze data by describing or describing the collected data as is without the intention of making generalized conclusions or generalizations. This analysis technique aims to determine the description of extracurricular activities and character building in students of SMPN 22 Makassar. Furthermore, inferential statistical analysis is to determine the normality of data, the relationship, and the influence between variables.

\section{RESULT AND DISCUSSION}

The data presented in this study are data obtained from the percentage level of questionnaire data that has been given to 71 respondents who became the research sample which is intended to determine the description and effect of extracurricular activities on the character formation of students of SMPN 22 Makassar which are described as follows.

\section{Extracurricular activities}

Based on the data analysis of each item regarding extracurricular activities, it can be seen from the whole for the indicators of skill and training/talent/achievement. This can be seen in the table below.

\section{Table 1.}

Summary of Data Analysis Results per Indicator of Extracurricular Activity Variables

\begin{tabular}{clcccc}
\hline Number & \multicolumn{1}{c}{ Indicator } & $\mathbf{n}$ & $\mathbf{N}$ & $\mathbf{\%}$ & Category \\
\hline 1. & Krida & 1788 & 3550 & 50,36 & $\begin{array}{c}\text { Good enough } \\
\text { Good }\end{array}$ \\
2. & Training, / Talent / & 2251 & 3550 & 63,40 & \\
\hline & Achievement & & & & Pretty good \\
\hline
\end{tabular}

Source: Data Processing Results 2020

$$
\begin{aligned}
\% & =\frac{4039}{20 \times 5 \times 71} \times 100 \\
& =\frac{4039}{7100} \times 100 \\
& =56,88
\end{aligned}
$$




\section{Jurnal Office: Jurnal Pemikiran Ilmiah dan Pendidikan Administrasi Perkantoran \\ Vol. 7, Number. 1, January-June 2021, Hal 1-10}

The results of the analysis in the table of extracurricular activity variables above show that the krida indicator is at the percentage level of 50.36 percent and is in a fairly good category and the training/talent/achievement indicators are at the percentage level of 63.40 percent and is in a good category. So, the results of the descriptive analysis above show that the percentage level of the extracurricular activity variable at SMPN 22 Makassar is 56.88 and is in the good enough category in terms of indicators, namely skill and training/talent/achievement. This is in line with the opinion of the Regulation of the Minister of Education and Culture of the Republic of Indonesia Number 81A of 2013 in Kompri (2015) that the types of extracurricular activities take several forms, namely 1) Krida; covering Scouting, Basic Student Leadership Training, Youth Red Cross, Heritage Flag Raising Troops and others; 2) Scientific works, including Youth Scientific Activities, scientific mastery activities, and academic abilities, research, and others. 3) Talent/achievement training/sports, including the development of sports, arts, and culture, love for nature, journalism, theater, religion, or other types.

The results of the data processing are strengthened by the results of interviews by counseling guidance teachers (BK) as well as extracurricular mother coaches Damaris Lulunbara, S.Pd on September 18, 2020, which said that extracurricular activity, really took up students' free time that was previously spent doing negative things to be useful because of the presence of several extracurricular activities so that students became more interested and felt challenged to participate in extracurricular activities so that less free time to play or do negative things

\section{Characters}

Based on data analysis of each item regarding student character, it can be seen from the whole for indicators of religion, discipline, cooperation, creativity, independence, democracy, and responsibility. This can be seen in the table below.

Table 2.

Summary of Data Analysis Results per Indicator of Extracurricular Activity Variables

\begin{tabular}{clcccc} 
Number & \multicolumn{1}{c}{ Indicator } & $\mathbf{n}$ & $\mathbf{N}$ & $\mathbf{\%}$ & Category \\
\hline 1. & Religious & 936 & 1065 & 87,88 & Very good \\
2. & Discipline & 880 & 1065 & 83,63 & Very good \\
3. & Hard work & 852 & 1065 & 80 & Very good \\
4. & Creative & 479 & 710 & 67,46 & good \\
5. & Independent & 778 & 1065 & 73,05 & good \\
6. & Democratic & 737 & 1065 & 69,20 & good \\
7. & Responsible & 903 & 1065 & 84,78 & Very good \\
\hline & total & $\mathbf{5 5 6 5}$ & $\mathbf{7 1 0 0}$ & $\mathbf{7 8 , 3 8}$ & good \\
\hline
\end{tabular}

Source: Data Processing Results 2020 


$$
\begin{aligned}
\% & =\frac{5565}{20 \times 5 \times 71} \times 100 \\
& =\frac{5565}{7100} \times 100 \\
& =78,38
\end{aligned}
$$

Based on the results of the descriptive analysis above, it shows that the percentage level of the character variable of students at SMPN 22 Makassar is 78.38 percent in the good category in terms of indicators of a religious character, discipline, hard work, creativity, independence, democratic and responsibility. The results of this study indicate that the character level is in a good category. This is in line with the opinion of (Fathurrohman et al. 2013) namely, the values developed in character education are religion, honest, disciplined, hard work, creativity, independence, democratic, curiosity, national spirit, love for the country, respect for achievement, friendly/communicative, love peace, love to read, care environment, social care, and responsibility.

The results of data processing are strengthened by the results of interviews by mothers of counseling guidance teachers Damaris, S.Pd on October 18, 2020, which said that with extracurricular activities where previously students did not understand about extracurricular organizations/activities, after taking extracurricular activities they began to understand what extracurricular activities were. Through that, the character of students after taking extracurricular activities gets better, where the level of discipline is very good. When they hold an activity, they cooperate and do it with full responsibility according to the assigned tasks

\section{The Influence of Extracurricular Activities on Character Building of Students of SMPN 22 Makassar}

Extracurricular activities are one of the potential media to build character and improve student academic quality. So through extracurricular activities, it is hoped that it can develop abilities and a sense of social responsibility as well as the potential and achievement of students while the character is a psychological trait or character or character that distinguishes a person from another

Table 3.

Summary of Data Normality Testing Results with Sig. 5\%

\begin{tabular}{lcccc}
\hline \multicolumn{1}{c}{ Variable } & $\mathbf{X}_{\text {hitung }}$ & $\mathbf{X}_{\text {tabel }}$ & Df & information \\
\hline Extracurricular activities & 19.662 & 55,758 & 40 & Normal \\
Character & 21.718 & 41,337 & 28 & Normal \\
\hline
\end{tabular}

Source: Results of Statistical Analysis through the SPSS Program. 20

Based on the results of the data normality test analysis in Table 3, it is known that the extracurricular activity variable $(\mathrm{X})$ is declared to be normally distributed because it has met the price requirements. $x_{h}^{2}(19.662)$ smaller $(\leq)$ of the $x_{t}^{2}$ with df 40 amounting to 55,756 . 


\section{6 | Jurnal Office: Jurnal Pemikiran Ilmiah dan Pendidikan Administrasi Perkantoran Vol. 7, Number. 1, January-June 2021, Hal 1-10}

Likewise, the character variable $(\mathrm{Y})$ is stated to be normally distributed, because it has met the price requirements $x_{h}^{2} 21.718$ smaller than ${ }^{x_{t}^{2}}$ with df 28 amounting to 41.337

Table 4.

Summary of Product Moment Correlation Testing Results with Sig. 5\%

\begin{tabular}{ccccc} 
Model & R & R Square & Adjusted R Square & $\begin{array}{c}\text { Std. Error of the } \\
\text { Estimate }\end{array}$ \\
\hline 1 & $.437^{\mathrm{a}}$ & .191 & .180 & 7.341 \\
\hline
\end{tabular}

a. Predictors: (Constant), Extracurricular activities

b. Dependent Variable: Character

Source: Results of Data Analysis through the SPSS Program. 20

The results of the Product Moment correlation analysis in table 13 are obtained $r_{\text {count }}$ amounting to 0.437 which is then interpreted in the guideline table for the interpretation of the correlation coefficient so that it is said that the correlation coefficient is 0.437 in the interval 0.40-0.599 with a moderate level of relationship. Therefore, to test the significance of the relationship, namely whether the relationship found applies to the entire population, it is necessary to test its significance. Whether the correlation of these results is significant or not is compared $r_{\text {count }}$ with $r_{\text {table }}$ with a significance level of 5 percent and respondent $(N)=71$ it is obtained $r_{\text {tabel }}$ amounting to 0,235 (attachment 13).

Based on the analysis of the product-moment correlation test, it is stated that there is a significant relationship between extracurricular activities and the formation of student characters at SMPN 22 Makassar, because $r_{\text {count }}(0,437)$ bigger than $r_{\text {table }}(0,235)$ then $H_{0}$ rejected and $H_{a}$ accepted and the coefficient of determination is known, namely $r^{2}=0,191$ or of 19,1 the percent which means of the character variable is determined by extracurricular activities. While the remaining $80.9 \%$ is determined by external factors from other variables that have not been studied.

Table 5.

Summary of Simple Linear Regression Analysis Results

ANOVA $^{\mathrm{a}}$

\begin{tabular}{llccccc}
\hline Model & $\begin{array}{c}\text { Sum of } \\
\text { Squares }\end{array}$ & Df & Mean Square & F & Sig. \\
\hline 1 & Regression & 880.009 & 1 & 880.009 & 16.328 & $.000^{\mathrm{b}}$ \\
& Residual & 3718.724 & 69 & 53.895 & & \\
Total & 4598.732 & 70 & & & \\
\hline
\end{tabular}

a. Dependent Variable: Character

b. Predictors: (Constant), Extracurricular activities 
The F-test analysis through SPSS was obtained $F_{\text {count }}$ amounting to 16.328 and $F_{\text {table }}$ $(0,05: 1: 71)$ amounting to 3.98 which means $F_{\text {count }}$ bigger than $F_{\text {table }}$ because $F_{\text {count }}>F_{\text {table }}$ then $H_{0}$ rejected and $\mathrm{H}_{\mathrm{a}}$ received. So that directly the results of data processing in this study with the hypothesis that it is suspected that there is an influence of extracurricular activities on character building of students at SMPN 22 Makassar can be accepted.

\section{Discussion}

To understand more about the title "The Influence of Extracurricular Activities on Student Character Formation at SMPN 22 Makassar", the researchers reviewed several theses related to this issue. In the thesis Fitri Untari Ningrum with the title "The Influence of Extracurricular Activities on the Formation of Civic Disposition of Students of SMK Negeri 1 Semendawai Timur", which discusses the character-building but more to the character of the Civic Disposition of students where the civic disposition is a civic character with the results of extracurricular activities quite influential and in the strong category. The thesis Aiu Rofiq entitled "The Influence of Religious Extracurricular Activities on Student Character at SMAN 1 Sumpiuh, Banyumas Regency" discusses how much influence extracurricular religion has on student character. The results of this study have a positive and significant effect of religious extracurricular activities on student character. These theses discuss extracurricular activities and student character. Thesis Fitri Untari Ningrum by using the civic disposition character variable and thesis Aiu Rofiq using religious extracurricular variables.

\section{Extracurricular activities}

Extracurricular activities are a forum for carrying out activities to develop the potential, talents, interests, and spirit of leadership and social as well as the development of student characteristics. The results of this study indicate that the level of extracurricular activities is in a fairly good category, this is seen from the indicator 1) krida which includes Scouting, Basic Student Leadership Training, Youth Red Cross, Flags Raising Troops, and others. 2) Talent/achievement training/processing which includes the development of talents in sports, arts, and culture, love of nature, theater journalism, religion, or other types. The results of this study were to determine the effect of extracurricular activities on the character building of students.

This is in line with the opinion of the Regulation of the Minister of Education and Culture of the Republic of Indonesia Number 81A of 2013 in Kompri (2015) that the types of extracurricular activities take several forms, namely 1) Krida; covering Scouting, Basic Student Leadership Training, Youth Red Cross, Heritage Flag Raising Troops and others; 2) Scientific works, including Youth Scientific Activities, scientific mastery activities and academic abilities, research, and others; 3) Talent/achievement training/processing which includes the development of sports, arts, and culture, love of nature, theater journalism, religion or other types. 


\section{8 | Jurnal Office: Jurnal Pemikiran Ilmiah dan Pendidikan Administrasi Perkantoran \\ Vol. 7, Number. 1, January-June 2021, Hal 1-10}

\section{Characters}

Character is the values of universal human behavior that include all human activities, whether related to God or others. The results of this study indicate that the character level is in a good category. This can be seen from the indicators of a religious character, discipline, hard work, creativity, independence, democracy, and responsibility. Religious attitudes are attitudes and behaviors that must be possessed by students so that students are obedient in carrying out religious teachings, are tolerant and harmonious with other religions; discipline is very important for students, discipline is not only done and lived only because of a rule and policy that must be obeyed following those rules, but discipline is carried out because of one's awareness; hard work is a behavior that shows a serious effort in overcoming various obstacles to learning and assignments and completing tasks as well as possible; creative is the act of thinking and doing something to produce a new way or result from something that is already owned; independent is an attitude and behavior that is not easily dependent on others; democratic which is a way of thinking, behaving and acting that values the rights and obligations of oneself and others. A democratic attitude is needed so that students grow mutual respect, respect, and understand the various problems of their life wisely; and responsibility is a person's attitude and behavior to carry out his duties and obligations, which he should do for himself, society, the environment, the country, and God Almighty.

This is in line with the opinion of (Fathurrohman et al. (2013) namely, the values developed in character education are religion, honest, disciplined, hard work, creativity, independence, democratic, curiosity, national spirit, love for the country, respect for achievement, friendly/communicative, love peace, love to read, care environment, social care, and responsibility.

\section{The Influence of Extracurricular Activities on Character Building of Students of SMPN 22 Makassar}

The results of this study indicate that there is a significant effect of extracurricular activities on the character building of students of SMPN 22 Makassar. Based on the results of the analysis, it is known that the simple linear regression in the ANOVA table is obtained equal to $F_{\text {hitung }}$ (16.3289) $>F_{\text {tabel }}$ (3.98) which indicates that there is a significant effect of extracurricular activities on the character building of students of SMPN 22 Makassar. This means that the proposed hypothesis "it is suspected that there is an effect of extracurricular activities on the character building of students of SMPN 22 Makassar" is accepted with a "moderate" level of influence on the formation of student character formation. It can be explained that extracurricular activities are a place to channel students' talents and interests and can help students develop both interests, talents, and student character.

This is in accordance with the theory put forward by Sofan Amri, Dadang, dan Permendikbud Number 62 of 2014. Sofan Amri (Amri et al., 2011) argued that extracurricular activities are one of the most potential media for character building and improving student academic quality. Dadang ( Kompri 2015) in extracurricular purposes it is stated that extracurricular activities develop students' talents of interest in personal coaching efforts 
towards positive whole human development. Permendikbud Number 62 of 2014 also argued that extracurricular activities in education are developing the potential, talents, interests, personality, cooperation and optimal independence of students. So the results of the research and analysis that have been carried out can be concluded that there is an influence between extracurricular activities on the formation of meaningful student character $H_{0}$ rejected and $H_{a}$ received.

\section{CONCLUSION}

Based on the results of data analysis and discussion of the effect of extracurricular activities on the character formation of students at SMPN 22 Makassar, it can be concluded that the extracurricular activities of students of SMPN 22 Makassar are in the "good enough" category, this is viewed in terms of indicators of extracurricular activities, namely krida indicators and training indicators. if talent / achievement. The characterization of students of SMPN 22 Makassar is included in the "good" category, this is seen in terms of attitude indicators, namely religious, disciplined, hard work, creative, independent, democratic, and responsible. Based on the results of the product-moment correlation test, it states that there is a significant relationship between extracurricular activities on the formation of student characters at SMPN 22 Makassar, because $r_{\text {count }}(0,437)$ bigger than $r_{\text {table }}(0,235)$ then $\mathrm{H}_{0}$ rejected and $\mathrm{H}_{\mathrm{a}}$ accepted, which means that there is a fairly good effect on the formation of student characters at SMPN 22 Makassar and are in the medium category.

\section{REFERENCES}

Amri, S., Jauhari, A., \& Elisah, T. (2011). Implementasi Pendidikan Karakter dalam Pembelajaran. PT. Prestasi Pustakarya.

Annu, S., \& Sunita, M. (2013). Impact of Extracurricular Activities on Students. International Journal of Humanities and Social Science Invention.

Arhas, S. H. (2018). Metode Pembelajaran Black Knight. Apa? Mengapa? dan Bagaimana? Jurnal Ad'ministrare, 5(2), 165-172.

Darling, N., Caldwell, L. L., \& Smith, R. (2005). Participation in school-based extracurricular activities and adolescent adjustment. Journal of Leisure Research. https://doi.org/10.1080/00222216.2005.11950040

Darwis, M., Amelia, D., \& Arhas, S. (2019). The Influence of Teaching Variations on Student Learning Motivation at State Vocational High School 4 Makassar. International Conference on Social Science 2019 (ICSS 2019).

Eccles, J. S., Barber, B. L., Stone, M. R., \& Hunt, J. E. (2003). Extracurricular activities and adolescent development. Journal of Social Issues. https://doi.org/10.1046/j.00224537.2003.00095.x

Fathurrohman, P. H. P., Dr. Aa Suryana, M., \& Feni Fatriani, SH., M. H. (2013). Pengembangan Pendidikan Karakter (1st ed.). PT. Refika Aditama.

Fredricks, J. A. (2012). Extracurricular Participation and Academic Outcomes: Testing the Over-Scheduling Hypothesis. Journal of Youth and Adolescence. 
10 | Jurnal Office: Jurnal Pemikiran Ilmiah dan Pendidikan Administrasi Perkantoran Vol. 7, Number. 1, January-June 2021, Hal 1-10

https://doi.org/10.1007/s10964-011-9704-0

Hanung Cahyono. (2017). Perpres no. 87 Tahun 2017. 6 September 2017.

Kompri, M. P. . (2015). Manajemen Pendidikan (1st ed.). AR-RUZZ MEDIA.

Ma'rifataini, L. (2017). Pengaruh Kegiatan Intrakurikuler dan Ekstrakurikuler Terhadap Pembentukan Karakter Siswa Sekolah Menengah Atas Negeri (SMAN) 09 Bandar Lampung. EDUKASI: Jurnal Penelitian Pendidikan Agama Dan Keagamaan, 14(2), 171186. https://doi.org/10.32729/edukasi.v14i2.16

Niswaty, R., \& Arhas, S. H. (2019). The Effect of Learning Media on Progress Quality in Office Administration Program in Vocational School Negeri 1 Watampone Bone Regency. Journal of Physics: Conference Series, 1387. https://doi.org/10.1088/17426596/1387/1/012042

Pendidikan, M., Kebudayaan, D. A. N., \& Indonesia, R. (2014). UU RI Nomor 62 Tahun 2014. 53(9), 1689-1699.

Rozi, A., \& Sunarsi, D. (2020). The Influence of Motivation and Work Experience on Employee Performance at PT. Yamaha Saka Motor in South Tangerang. Jurnal Office, 5(2), 65-74.

Saleh, S., Jamaluddin, J., \& Arhas, S. H. (2019). IbM Supervisi Akademik Kepala Sekolah Dasar Berbasis Information Teknologi di Kecamatan Ulaweng Kabupaten Bone. Humanis, 18(2), 23-28.

Shulruf, B., Tumen, S., \& Tolley, H. (2008). Extracurricular activities in school, do they matter? Children and Youth Services Review. https://doi.org/10.1016/j.childyouth.2007.10.012

Sufriadi, S., Yuni, N. P., \& Jamaluddin, J. (2019). The Effectiveness of Communication Ethics in Achieving Learning Objectives at State Vocational High School 4 Makassar. Jurnal Office, 4(2), 63-78.

Sugiyono. (2017). Pendekatan Kuantitatif, Kualitatif, Kombinasi, $R \& D$ dan Penelitian Evaluasi. Alfa Beta.

Sugiyono. (2018). Metode Penelitian Pendidikan. Alfabeta. 